\title{
Developing The Firm Mosque Model As A Public Health Institution Through The Implementation Of Psychoacoustic On Loudspeaker Systems
}

\author{
Nurida Finahari' ${ }^{1}$, Alfiana ${ }^{2}$ \\ ${ }^{1}$ Mechanical Engineering Dept. of Technical Faculty of Widyagama University of Malang \\ 2Management Department of Economic Faculty of Widyagama University of Malang \\ Email: 1nfinahari@widyagama.ac.id \\ d. \\ https://doi.org/10.36526/gandrung.v2i1.1191
}

\begin{abstract}
Voices originating from the mosque, whether they are recitation, incidental activities or daily routine prayers, are still often interpreted as a source of noise. Not only because of the improper arrangement of the loudspeakers, but also because the mosque's recitals or takmirs generally do not understand the psychoacoustic aspect. Psychoacoustic is the study of the effect of sound exposure on the psychological aspects of the listeners. The use of psychoacoustic science could potentially change mosque sounds into therapeutic voices. The voices of recitation-based therapists have been encountered and researched, although in a limited scope. Building a mosque sound management and control system that is consistent within a psychoacoustic framework can transform potential noise into a natural sound that builds public health that runs automatically. The achievement of this hypothesis can be done from the application of a research and / or community service activity by educational institutions or related agencies.
\end{abstract}

Keyword: mosque, loudspeaker, psychoacoustic, public health

\section{Pendahuluan}

Lembaga masjid di Indonesia secara umum berfungsi sebagai tempat pelaksanaan kegiatan peribadahan rutin, dan belajar mengaji. Kegiatan tambahan biasanya hanya berbentuk aktivitas kesenian berbasis ritual. Di masa Nabi, masjid tidak sekedar menjadi pusat ibadah, tetapi juga madrasah yang berfungsi sebagai lembaga pendidikan, tempat pertemuan untuk membahas permasalahan perekonomian dan politik. Masjid juga berfungsi sebagai pusat pengembangan budaya dan pelaksanaan sistem peradilan (Parstoday, 2018). Pada zaman itu bisa disebutkan bahwa masjid adalah pusat aktivitas dan lembaga pemberdayaan masyarakat. Penyempitan peran masjid ini makin menjadi sorotan masyarakat karena adanya kecenderungan pengelola masjid untuk lebih mengedepankan pembangunan fisik tanpa fungsi manajerial yang profesional. Kemanfaatan hal itu lebih bersifat simbolik eksklusif. Peran dan sentuhan teknologi sedikit berjejak dalam aktivitas masjid sehingga semakin teralienasi dari kehidupan kemasyarakatan. Masjid dinilai tidak mengikuti perkembangan jaman sehingga terkesan monoton, membosankan jamaahnya, dan tidak menarik minat khususnya bagi kalangan remaja 
Permasalahan terbaru yang menerpa kelembagaan masjid pada tahun-tahun terakhir ini terkait dengan keluhan atas kebisingan yang muncul dari pengeras suara. Permasalahan ini terkait erat dengan penguasaan teknologi dan tingkat pemahaman pengelola masjid terhadap teknologi akustik dan kesehatan. Permasalahan kebisingan, terlepas dari sumber suaranya, telah diatur dalam UU Keselamatan dan Kesehatan Kerja, dimana untuk area perumahan ditetapkan ambang kebisingannya adalah 45-55 dB. Pengukuran tidak resmi yang dilakukan oleh Armand (2015), salah seorang staf pengajar di Universitas Hasanuddin Makassar, suara masjid terukur mencapai $65 \mathrm{~dB}$. Dengan mengingat bahwa secara rutin masjid bersuara minimal 5 kali sehari, maka paparan kebisingan akibat suara masjid adalah permasalahan serius yang bisa mengancam kesehatan masyarakat. Hal ini makin diperparah oleh munculnya pandemi Covid 19 dimana beberapa masjid telah menjadi sumber kluster penderita positif Covid 19 yang bermula dari aktivitas keagamaan yang diselenggarakannya. Kondisi ini seolah menegaskan stigma masyarakat bahwa jamaah masjid terkungkung oleh dogma irasional kuno. Masjid dianggap tidak mampu menjadi sumber solusi permasalahan bahkan menjadi bagian dari masalah. Solusi umum atas permasalahan-permasalahan tersebut, diutarakan oleh Jahroni (Wahid, 2019) berupa pemberlakuan perubahan manajemen, baik untuk manajemen kegiatan maupun manajemen pendanaan, dan penguatan sumber daya manusia.

Jika difokuskan pada permasalahan produksi suara, masjid sebenarnya selalu memiliki kelompokkelompok pengajian, yang berpotensi menghasilkan suara-suara menyenangkan, bahkan bersifat terapis. Suara terapis ini berpengaruh positif pada kesehatan manusia, baik fisik maupun psikisnya. Sayangnya potensi ini juga kurang disadari. Kajian tentang suara terapis dipelajari dalam bidang ilmu psikoakustik. Psikoakustik mempelajari pengaruh suara terhadap aspek psikologis manusia yang mempersepsikan karakteristik fisik suara dasar (lakovides et al., 2004). Karakteristik psikoakustik musik meliputi pitch, intensitas, timbre, dan ritme. Ritme merupakan variabel waktu (Krumhansl, 2000). Menerapkan teknik psikoakustik pada berbagai sumber suara yang dihasilkan masjid akan menjadi satu teknologi aplikatif yang bisa mengubah paradigma negatif masjid menjadi positif. Hal itu sekaligus bisa dikembangkan ke arah peningkatan manfaat masjid sebagai alternatif sumber kesehatan masyarakat secara harfiah.

\section{Metode}

Artikel ini membahas tentang potensi kegiatan pengabdian masyarakat yang bisa dikembangkan dari analisis hasil penelitian tentang psikoakustik, dengan target sasaran lembaga keagamaan masjid. 
GANDRUNG: Jurnal Pengabdian Kepada Masyarakat ISSN: 2721-6136 (Online)

Kerangka pikir disusun dari sejumlah kajian teoritis untuk diterapkan sesuai isu-isu terkini tentang lembaga masjid ini. Hasil akhir yang diharapkan adalah munculnya kejelasan tentang ruang lingkup dan metode-metode yang mungkin diterapkan dalam kegiatan pengabdian masyarakat, jika akan dilakukan.

\section{Hasil dan Diskusi}

\section{Hasil}

\section{Sekilas Tentang Psikoakustik}

Secara fisiologis, bunyi juga bisa didefinisikan sebagai persepsi psikofisik dari impuls syaraf akibat stimulasi korteks akustik otak (F. Everest, 1987). Pada umumnya istilah bunyi mengacu pada kondisi gelombang yang tidak menghasilkan persepsi psikologis atau sering disebut sebagai suara tanpa makna. Sebaliknya istilah suara sering digunakan untuk menyebutkan bunyi yang mengandung atau memunculkan persepsi psikologis tertentu. Dengan kata lain suara adalah istilah yang digunakan untuk menyebut bunyi bermakna.

Ilmu yang mempelajari mekanika bunyi, khususnya yang berkaitan dengan manipulasi dan respon terhadap gelombang bunyi, dikenal dengan sebutan akustik (Bauer, 2002). Akustik mengkhususkan kajiannya pada gelombang suara terdengar, dalam arti memiliki rentang frekuensi dalam batas pendengaran telinga manusia. Teori-teori dasar akustik dikembangkan oleh seorang musisi dan ahli fisika bernama Ernst Chladni (1756-1827). Chladni meneliti elemen-elemen dasar akustik seperti vibrasi dan pitch (rentang suara). Salah satu penelitiannya menunjukkan adanya respon spesifik material terhadap paparan bunyi. Hamparan pasir pada eksperimen Chladni menunjukkan pola geometris yang berbeda terhadap paparan frekuensi bunyi yang berbeda. Teori dasar ini kemudian berkembang dan memunculkan cabang-cabang ilmu baru termasuk yang disebut Simatiks (Cymatics). Simatiks adalah ilmu yang mempelajari manifestasi bunyi, gelombang dan vibrasi dalam bentuk khas sebagai akibat dari perbedaan medium yang dilaluinya. 
GANDRUNG: Jurnal Pengabdian Kepada Masyarakat ISSN: 2721-6136 (Online)

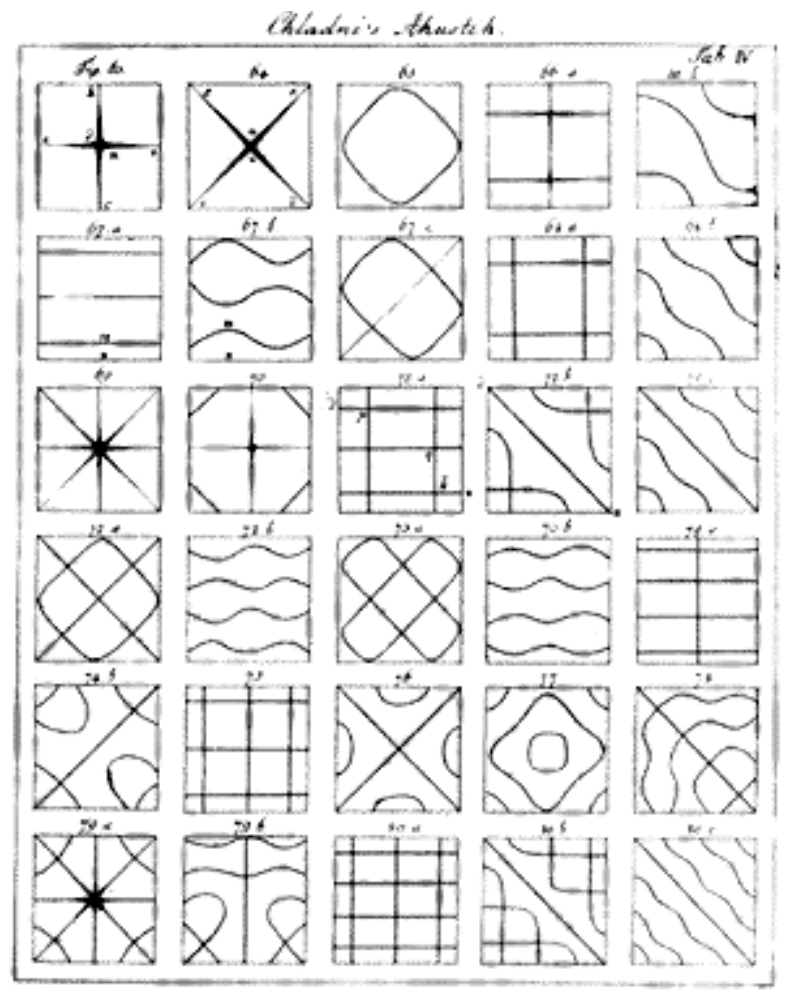

Gambar 1.: Eksperimen Chladni menunjukkan reaksi material terhadap perbedaan frekuensi paparan bunyi (Bauer, 2002)

Hubungan antara komponen fisik dan psikologis suara tampak dalam proses pendengaran terhadap musik. Musik merupakan upaya manusia untuk mengekspresikan emosi (lakovides et al., 2004). Hal itu menyebabkan musik dapat mempengaruhi suasana hati, dan membangkitkan perasaan. Musik berperan penting dalam proses komunikasi dan penyampaian informasi dalam bentuk elemenelemen semantik dan emosional (Platel et al., 2001). Elemen-elemen itu mengindikasikan keterlibatan sistem syaraf pusat dan sistem auditori perifer dalam proses integrasi dan interpretasi sinyal suara.

\section{Karakteristik Musikal}

Suara pengajian secara definisi bisa dikategorikan sebagai suatu nyanyian, yang bisa diiringi dengan musik ataupun tidak. Hal ini menjadi dasar untuk memperlakukan suara pengajian sebagai unsur musik. Mengacu pada hal tersebut, analisis ataupun inovasi terhadap suara pengajian sebaiknya dilandasi pemahaman terhadap unsur-unsur musikal. Unsur-unsur yang digunakan untuk menjelaskan karakter musik (Adytya, 2020) adalah : 
a. Melodi

Melodi adalah tinggi, rendah dan panjang pendeknya nada yang terdapat di dalam musik. Melodi adalah kesatuan frase yang sudah disusun dari nada dengan urutan, interval serta tinggi yang sudah diatur. Dengan adanya melodi, maka akan membuat musik semakin berwarna. Sehingga dapat didengar dan dinikmati oleh masyarakat pendengarnya.

b. Birama

Birama atau disebut juga sebuah ketukan secara berulang-ulang. Ketukan birama ini hadir dalam waktu yang bersamaan dan merupakan salah satu unsur pembentuk sebuah karya seni musik. Biasanya birama ini dituliskan dengan menggunakan angka seperti $2 / 4,2 / 3,3 / 4$, begitu seterusnya, angka yang berada di atas tanda '/' itu menunjukkan nilai nada dalam satu ketukan. Birama ini terbagi dalam 2 jenis jika dilihat dari bilangan penyebutnya. Akan disebut birama binair jika nilai penyebutnya genap, sementara yang berpenyebut ganjil disebut birama tenair.

c. Pitch

Pitch, merupakan sensasi subyektif yang digunakan untuk menyebutkan ketinggian suara. Persepsi manusia terhadap pitch dapat memunculkan ilusi auditoris. Pitch lebih dekat hubungannya dengan frekuensi jika dibandingkan dengan variabel-variabel gelombang bunyi lainnya. Semakin tinggi frekuensi gelombang suara, pitch yang terdengar juga semakin tinggi, dan sebaliknya untuk frekuensi rendah. Hubungan pitch dan frekuensi bukanlah hubungan linier sederhana, meskipun terjadi pada intensitas suara yang sama.

d. Ritme atau irama

Ritme atau irama juga merupakan unsur-unsur musik. Ritme atau irama ini adalah rangkaian gerak beraturan yang menjadi unsur dasar dari sebuah musik. Tak hanya itu, ritme atau irama ini juga memiliki arti lain yakni pergantian panjang pendek, tinggi rendah serta keras lembut nada atau bunyi dalam satu kesatuan rangkaian musik. Memang jika didengarkan secara sekilas ritme musik tidak dapat dirasakan, perlu dilakukan pengulangan pendengaran agar dapat mengetahui struktur iramanya.

e. Tempo

Tempo adalah ukuran kecepatan birama lagu yang juga menjadi salah satu unsur-unsur karya seni musik. Jika lagu dimainkan dengan cara semakin cepat, maka semakin tinggi atau besar pula nilai tempo musik tersebut. Tempo sendiri memiliki beberapa bagian kategori antara lain, lambat sekali (largo), lebih lambat (lento), lambat (adagio), sedang (andante), sedang sedikit cepat (moderato), 
cepat (allegro), lebih cepat (vivace) dan yang terakhir adalah cepat sekali (presto).

\section{f. Tangga nada}

Tangga nada merupakan urutan dari suatu nada yang sudah disusun hingga membentuk tangga. Umumnya nada terbagi menjadi dua yakni diatonik dan pentatonik. Nada diatonik adalah tangga nada yang terdiri dari 7 buah nada dengan jenis jarak 1/2 dan 1. Berbeda dengan tangga nada pentatonik yang memiliki nada pokok sebanyak lima saja. Tangga nada memiliki satu nada dasar yang diikuti oleh nada lain (tinggi atau rendah) dengan pola interval tertentu hingga menimbulkan ciri khas.

g. Harmoni

Harmoni merupakan keselarasan paduan nada yang dimainkan dalam suatu musik atau sekumpulan nada yang jika dimainkan secara bersama-sama akan mampu menghasilkan bunyi yang terdengar indah. Harmoni juga memiliki arti lain yakni rangkaian akor-akor yang disusun selaras dan dimainkan sebagai iringan musik. Akor tersebutlah yang pada nantinya akan dijadikan pengiring melodi.

h. Timbre

Timbre yang merupakan kualitas atau warna bunyi terdapat dalam sebuah karya seni musik. Misalnya timbre yang dihasilkan dari alat musik tiup akan berbeda dari timbre yang dihasilkan alat musik petik, meski dimainkan pada nada yang sama. Jadi timbre adalah kualitas suara musik yang didasarkan dari material dan bentuk alat musiknya.

i. Dinamika Suara

Dinamika adalah tanda untuk memainkan nada dengan volume nyaring atau lembut. Dinamika juga merupakan salah satu dari unsur-unsur musik. Dinamika memiliki fungsi penting yaitu menunjukkan nuansa lagu, bisa sedih, senang, agresif dan lain sebagainya. Dinamika ini merupakan salah satu unsur musik yang dapat menggambarkan emosi dan menyampaikan perasaan pada sebuah lagu.

\section{j. Ekspresi}

Ekspresi suara musik dapat diartikan sebagai ungkapan perasaan hati. Unsur ekspresi ini pada nantinya akan dituangkan ke dalam sebuah pertunjukan saat memainkan musik. Ekspresi kadang dianggap sebagai unsur musik, kadang juga tidak. Ekspresi musik sering dinyatakan sudah diwakili oleh dinamika, sementara ekspresi lebih mirip dengan unsur drama yang menunjukkan karakter wajah saat memerankan watak tertentu. 
GANDRUNG: Jurnal Pengabdian Kepada Masyarakat ISSN: 2721-6136 (Online)

\section{Kelompok Pengajian Sebagai Sumber Suara}

Kelompok pengajian adalah kelompok sosial umum yang banyak ditemui di setiap unit masyarakat, biasanya di tingkat RW. Di beberapa daerah bahkan ada kelompok pengajian berjenjang dari level RT hingga kelurahan/desa. Hal ini banyak ditemui di negara-negara berpenduduk mayoritas muslim dengan sebutan majelis taklim (Anonim, 2018). Meskipun sifatnya nonformal, tetapi majelis taklim memiliki peran penting dalam masyarakat. Dari segi fungsinya, majelis taklim bertujuan sebagai (Alawiyah, 1997):

a. tempat belajar yang akan mendorong pengalaman ajaran agama

b. wadah kontak sosial untuk bersilaturahim

c. pewujud minat sosial yang mengarah pada peningkatan kesejahteraan lingkungannya

Majelis taklim juga bisa dikelompokkan dari sistem pengorganisasiannya, yaitu :

a. Berbentuk kelompok masyarakat, biasanya dalam wujud takmir masjid, tanpa badan hukum tetapi mendapatkan pengakuan dari pemerintah setempat

b. Berbentuk yayasan

c. Berbentuk ormas

d. Organisasi di bawah ormas

e. Organisasi di bawah orsospol

Jamaah, pengikut, majelis taklim biasanya dibedakan dalam kelompok gender dan usia, sehingga lazim ditemukan adanya majelis taklim bapak-bapak, ibu-ibu, remaja, dan anak-anak. Sangat jarang ditemukan adanya majelis taklim yang berjamaah campuran.

Dengan mengacu pada pengelompokan majelis taklim/grup pengajian, maka suara manusia yang dijadikan sebagai sumber suara terapis bisa dikelompokkan dalam level-level akustik berdasarkan gender dan usia. Ini terkait dengan karakteristik pitch suara, yaitu tinggi rendahnya nada yang bersumber dari getaran sumber suara. Pitch suara manusia berbeda-beda untuk kelompok gender dan usia, tetapi tidak bisa dilakukan penyesuaian mengikuti suatu standar karena sumber suara manusia adalah pita suara di dalam batang tenggorokan. Pengendalian pitch suara manusia biasanya dilakukan dengan mengikuti atau menyelaraskan suara terhadap melodi alat musik yang sudah diatur mengikuti pitch standar, yaitu nada A terukur berfrekuensi $440 \mathrm{~Hz}$ (Irianto, 2009). Hal ini berarti bahwa jamaah majelis taklim/kelompok pengajian perlu diberikan pelatihan akustik yang meliputi teori praktis dan praktek teknik pengendalian suara atau olah vokal. 
GANDRUNG: Jurnal Pengabdian Kepada Masyarakat ISSN: 2721-6136 (Online)

\section{Transmisi Gelombang Suara Dan Sistem Pengeras Suara}

\section{a. Media transmisi.}

Gelombang suara hanya dapat merambat melalui medium. Medium didefinisikan sebagai substansi material (gas, benda padat, cairan dan plasma) yang dapat dilalui gelombang energi. Substansi plasma merupakan substansi khusus. Dari tinjauan fisika dan kimia, plasma merupakan substansi yang mirip dengan gas tetapi memiliki porsi padatan berbentuk partikel terionisasi. Partikel ini merupakan substansi pembawa muatan sehingga sangat responsif terhadap medan elektromagnetik. Sifat-sifat fisik plasma memiliki kemiripan dengan sifat-sifat fisik gas, padatan maupun cairan.

Pada saat tidak terdapat medium dalam bentuk material (ruang hampa), suara tidak dapat ditransmisikan secara langsung. Dalam hal ini gelombang suara harus diubah terlebih dahulu menjadi gelombang elektromagnetik. Gelombang elektromagnetik bisa berbentuk cahaya atau gelombang radio. Pada umumnya gelombang suara diubah menjadi gelombang radio untuk dapat ditransmisikan melalui ruang hampa. Proses perubahannya memerlukan serangkaian peralatan elektronik.

Media transmisi dapat diklasifikasikan sebagai berikut:

1. Media linier, dimana sembarang gelombang dapat bersuperposisi di sembarang titiknya. Media ini biasanya merupakan media tanpa batasan area penyebaran.

2. Media terbatas, merupakan medium yang dibatasi area penyebarannya.

3. Media seragam atau media homogen, merupakan medium yang sifat-sifat fisiknya tidak mengalami perubahan di setiap titiknya.

4. Media isotropik, adalah medium yang memiliki sifat-sifat fisik yang sama pada arah-arah penyebaran yang berbeda.

\section{b. Mekanisme transmisi.}

Transmisi gelombang suara dalam medium memerlukan adanya elastisitas dan inersia partikelpartikel medium (F. A. Everest, 1987). Sifat-sifat fisik tersebut diperlukan untuk mengembalikan kondisi medium pada keadaan semula sebelum dilalui gelombang suara. Pada saat sumber suara membangkitkan gelombang, perubahan tekanan yang menimpa partikel menyebabkan partikel tersebut, karena massanya (sifat inersia), menerima momentum dan meneruskannya pada partikel di sebelahnya. Kondisi tersebut terjadi berurutan terus menerus hingga gelombang berhenti. Momentum yang diterima partikel menyebabkan pergeseran partikel dari posisinya semula. Elastisitas medium menyediakan gaya 
GANDRUNG: Jurnal Pengabdian Kepada Masyarakat ISSN: 2721-6136 (Online)

elastis yang mampu menarik kembali partikel ke posisi semula. Jadi pada saat gelombang melalui medium, partikel-partikel medium bergetar di sekitar posisinya. Hal ini bisa dimisalkan tiupan angin yang menyebabkan timbulnya gerakan vibratoris pada ladang gandum tetapi ujung-ujung batang gandum tetap terayun-ayun pada posisinya. Dapat disimpulkan bahwa transmisi gelombang suara pada medium pada dasarnya merupakan proses transmisi energi akibat perubahan tekanan, bukan transmisi partikel medium.

\section{c. Kecepatan transmisi.}

Istilah kecepatan sering dipertukarkan dengan istilah laju. Meskipun sama-sama mengindikasikan 'kecepatan' tetapi laju mengacu pada tingkat perubahan posisi per unit waktu. Kecepatan, dalam hal ini, juga mengacu pada perubahan posisi yang nilainya sama dengan laju tetapi memiliki variabel arah gerakan. Hal ini menunjukkan bahwa kecepatan merupakan besaran vektor yang memiliki nilai dan arah sedangkan laju merupakan besaran skalar yang hanya memiliki nilai saja. Istilah laju sebenarnya lebih tepat diterapkan untuk transmisi gelombang suara karena umumnya arah transmisi tidak banyak dipersoalkan. Tetapi untuk selanjutnya akan digunakan istilah kecepatan karena lebih umum digunakan.

Telah dibahas sebelumnya bahwa yang sesungguhnya merambat pada proses transmisi gelombang suara adalah energi yang ditimbulkan oleh perbedaan tekanan bolak balik dari aktivitas sumber suara. Kecepatan transmisi suara adalah kecepatan proses transfer energi dari satu partikel medium ke partikel yang bersebelahan. Kecepatan transmisi suara berbeda dengan kecepatan getaran partikel akibat terbentur gelombang tekanan. Kecepatan transmisi suara di udara bernilai konstan selama temperaturnya konstan dan diukur sekitar $350 \mathrm{~m} / \mathrm{s}$ (1 Mach) atau setara dengan 785 mil per jam. Dengan kata lain, gelombang suara mampu mencapai jarak $1 \mathrm{~km}$ hanya dalam waktu 3 detik.

Kecepatan transmisi gelombang suara masih dipengaruhi karakteristik medium meskipun sebatas pada temperatur. Nilai kecepatan sebagaimana disebut di atas diukur pada suhu $20^{\circ} \mathrm{C}$. Nilai kecepatan tersebut tidak dipengaruhi tekanan dan densitas medium yang dilalui. Pada medium gas, berat molekul gas dan kemampuan medium menyerap energi juga mempengaruhi nilai kecepatan transmisi.

\section{d. Sistem Pengeras Suara}

Sistem pengeras suara merupakan peralatan elektronika yang umumnya digunakan dalam suatu pementasan (Padmodarmaya, 1987) atau suatu tampilan yang memerlukan penyiaran suara dalam lingkup luas dan/atau transmisi jarak jauh. Dasar-dasar cara kerja sistem pengeras suara menjadi 
berbeda untuk penyiaran langsung dari iringan atau ilustrasi yang menggunakan sumber bunyi asli, penyiaran rekaman dari sumber bunyi aslinya, dan proses merekam sumber bunyi. Sistem pengeras suara masjid termasuk pada kategori pertama dan kedua, yaitu bisa menyiarkan suara secara langsung atau suara rekaman. Secara umum komponen sistem pengeras suara yang digunakan masjid terdiri atas mic (mikrofon), amplifier, dan loud speaker. Penyetelan ketiga jenis peralatan tersebut sangat berpengaruh terhadap kualitas suara yang dihasilkan. Selain itu setiap komponen tersebut memiliki kapasitas masing-masing yang tidak bisa dilampaui. Hal ini menuntut pemahaman tentang luas ruangan yang dilingkupi, dan/atau radius jangkauan lingkungan yang diinginkan dengan batasan level kebisingan yang telah ditetapkan.

Mikrofon yang berfungsi sebagai penangkap suara pertama juga perlu diatur sesuai kapasitas individualnya. Sensitifitas mikrofon dalam menangkap suara akan berpengaruh terhadap suara-suara ikutan di sekitar sumber suara untuk ikut tertangkap sebagai suara pengganggu (noise). Jarak ideal mikrofon terhadap sumber suara juga menentukan kualitas luaran suara yang disiarkan. Penggunaan jenis-jenis mikrofon yang berbeda juga menentukan kualitas luaran. Dalam hal ini dikenal beberapa jenis mikrofon, yaitu :

a. Mikrofon Omni, bersifat non directional dapat menangkap suara dari berbagai arah.

b. Mikrofon Be Directional, menangkap suara dari dua arah.

c. Mikrofon Uni Directional, hanya menangkap suara dari satu arah.

d. Mikrofon Meja, yang bertangkai pendek.

e. Mikrofon Lapel, yang dapat dikaitkan pada baju.

f. Mikrofon Boom, berpenyangga panjang.

Penataan sistem pengeras suara sebenarnya banyak dipengaruhi oleh konsep-konsep tata laksana panggung. Suara adalah salah satu komponen yang ditata untuk mendukung efek pencahayaan, tampilan panggung, tata rias, kostum, dan ekspresi pelakon untuk membangun suasana lakon dan menghasilkan efek emosional terhadap penonton. Yang membedakan dengan penataan sistem pengeras suara adalah bahwa tata panggung maksimal yang ditampilkan pada kegiatan masjid hanyalah ekspresi penceramah dan suara saja. Ekspresi penceramah hanya bisa dilihat oleh mereka yang berada dalam ruang masjid, sementara efek suara bisa juga diperdengarkan keluar masjid. Mengingat penyiaran suara menempati prioritas utama, dan seringnya adalah satu-satunya yang ditransmisikan ke lingkungan, kualitas suara luaran yang bagus sudah semestinya menjadi prioritas utama. Ini termasuk juga pemilihan spesifikasi peralatan-peralatan yang tepat untuk mentransmisikan suara tersebut sesuai konsep-konsep 
GANDRUNG: Jurnal Pengabdian Kepada Masyarakat ISSN: 2721-6136 (Online)

fisika transmisi gelombang suara dalam medium udara.

\section{Kajian Suara-Suara Terapis}

Terapi musik klasik umum dikaitkan dengan kondisi fisiologis dan psikologis (Finahari et al., 2016). Penelitian berbasis tindakan telah dilakukan pada bidang-bidang keperawatan di Indonesia untuk menguji efektifitas terapi musik. Terapi musik klasik telah terbukti menurunkan tekanan darah penderita hipertensi pra-lansia (Rina P et al., 2017), gubahan Mozart berhasil menurunkan dismenorea (Wati et al., 2018), dan meredakan nyeri pasca operasi fraktur. Pembedahan optalmik memerlukan keterjagaan tekanan darah arterial, dan denyut jantung. Ini bisa dilakukan dengan memperdengarkan musik klasik, sekaligus untuk mengendalikan laju pernafasan (Camara et al., 2008), karena rasa sakit, periode dan lama perawatan, kecemasan, kelelahan, kenyamanan fisik, relaksasi, suasana hati, spiritualitas, energi, dan kualitas hidup, bisa dikendalikan dan dibangun melalui terapi musik. Bagi wanita Jawa yang akan melahirkan, suara Langgam lebih efektif dari musik klasik untuk menurunkan rasa nyeri dan kecemasan (Safitri, 2012). Hal ini menunjukkan bahwa latar belakang budaya diduga ikut berpengaruh, sehingga musik tradisional mulai diteliti sebagai media terapi (Wati et al., 2018)(Camara et al., 2008) Dapat dilihat bahwa terapi musik berdampak sama dengan obat penenang dan anti kecemasan, sehingga dapat digunakan sebagai pengganti obat-obatan (Maratos et al., 2009). Contoh-contoh ini menunjukkan bahwa terapi musik telah mulai menjamah area intervensi fisiologis.

Bacaan AI Quran dan suara pengajian sudah banyak diteliti juga berefek terapis. Suara murottal dinilai secara signifikan lebih mampu dalam menurunkan tingkat nyeri dan menjaga kestabilan tandatanda vital pasien pasca bedah, dibandingkan dengan suara musik klasik (Rilla et al., 2014). Hal yang sama juga terjadi pada saat suara murottal diperdengarkan pada post orif-fractur (Purnamaningtyas, 2019). Suara murottal tersebut berperan memicu relaksasi. Terapi pembacaan AI Quran juga dinyatakan bisa menjadi sarana terapi untuk permasalahan emosi dan kemampuan motorik wicara anak-anak penderita autis (Mohamad et al., 2013). Meskipun tidak dijelaskan bagaimana cara kerja bacaan tersebut dalam memunculkan pengaruhnya, peneliti tersebut meyakini bahwa selain aspek hidayah agamis, bacaan Al Quran disebut meningkatkan komunikasi antara otak kanan dan kiri yang bertanggung jawab terhadap perkembangan motorik bahasa dan emosinal. Beberapa hasil penelitian ini menunjukkan potensi positif suara spiritual dari masjid terhadap kesehatan jasmani dan rohani pendengarnya. 


\section{Diskusi}

Pemahaman tentang pengendalian pitch suara terkait dengan pemastian kemampuan pembuat suara untuk melingkupi rentang tinggi rendahnya suara dalam satu rangkaian nyanyian. Jika diterapkan pada satu kelompok paduan suara, dalam hal ini kelompok pengajian, maka kemampuan kolektif kelompok tersebut untuk mengendalikan pitch suara dalam menghasilkan harmoni, akan menghasilkan suara pengajian yang indah dan enak didengarkan. Memberikan pemahaman tentang unsur-unsur musikal dalam pengajian, bisa dilakukan melalui penyuluhan, atau kursus singkat oleh guru-guru olah vokal atau praktisi seni. Sejauh ini hal tersebut belum pernah dilakukan dalam masyarakat masjid. Pembelajaran dalam pengajian hanya dilakukan sebatas pada tata cara pengucapan dan hafalan bacaan surat-surat. Pada level seni membaca AI Quran, yang umum dilakukan adalah model musabaqah tilawatil Al Quran yang bersifat kemampuan membaca dan melagukan Al Quran secara indah tetapi individual. Ini jarang diperdengarkan di masjid, tidak untuk aktivitas harian. Pelatihan rutin untuk olah vokal bisa dijadwalkan secara rutin sebagai satu kegiatan pengabdian masyarakat oleh institusi-institusi pendidikan maupun dinas terkait.

Pemahaman tentang pitch juga bisa diterapkan pada pelafal adzan. Secara umum pelafal adzan juga mengandalkan kemampuan individual untuk memperdengarkan adzan yang merdu. Kemampuan individual ini juga tidak muncul dari pelatihan khusus oleh takmir masjid. Namun demikian, kemampuan invidual dalam memperdengarkan suara adzan yang merdu, juga masih dipengaruhi oleh kualitas sistem pengeras suara yang dimiliki masjid. Pada umumnya sistem pengeras suara masjid ditata seadanya, dan hanya mengacu pada keras tidaknya suara yang muncul di lingkungan. Kualitas suara akhir yang terdengar oleh lingkungan hampir tidak dipertimbangkan sama sekali. Penataan sistem pengeras suara yang memperhatikan aspek kebisingan dan akustik perlu disampaikan dan diajarkan pada pengurus masjid. Sarana pengukuran suara luaran sistem pengeras suara juga perlu dimiliki dan diaplikasikan di masjid, baik untuk pengendalian suara yang didengar jamaah di dalam maupun di luar masjid. Informasi ini bisa disampaikan melalui aktivitas pengabdian masyarakat juga.

Jika ketiga aspek tersebut di atas bisa dibangun secara rutin dan berkelanjutan, dapat diharapkan bahwa pada saatnya nanti, suara-suara pengajian dari masjid akan bertransformasi menjadi suara-suara lingkungan alami yang indah dan merdu. Ini akan bersifat terapis, sehingga dalam jangka panjang, akan menghasilkan efek penyehatan terhadap lingkungan secara tidak tersadari. Konsepsi ini bisa dirangkum secara skematis sebagaimana ditunjukkan pada Gambar 2. Proses transformasi ini akan menarik untuk didesain dan diikuti sebagai satu tema penelitian dan/atau kegiatan masyarakat yang bersifat teknologi 
GANDRUNG: Jurnal Pengabdian Kepada Masyarakat ISSN: 2721-6136 (Online)

tepat guna.

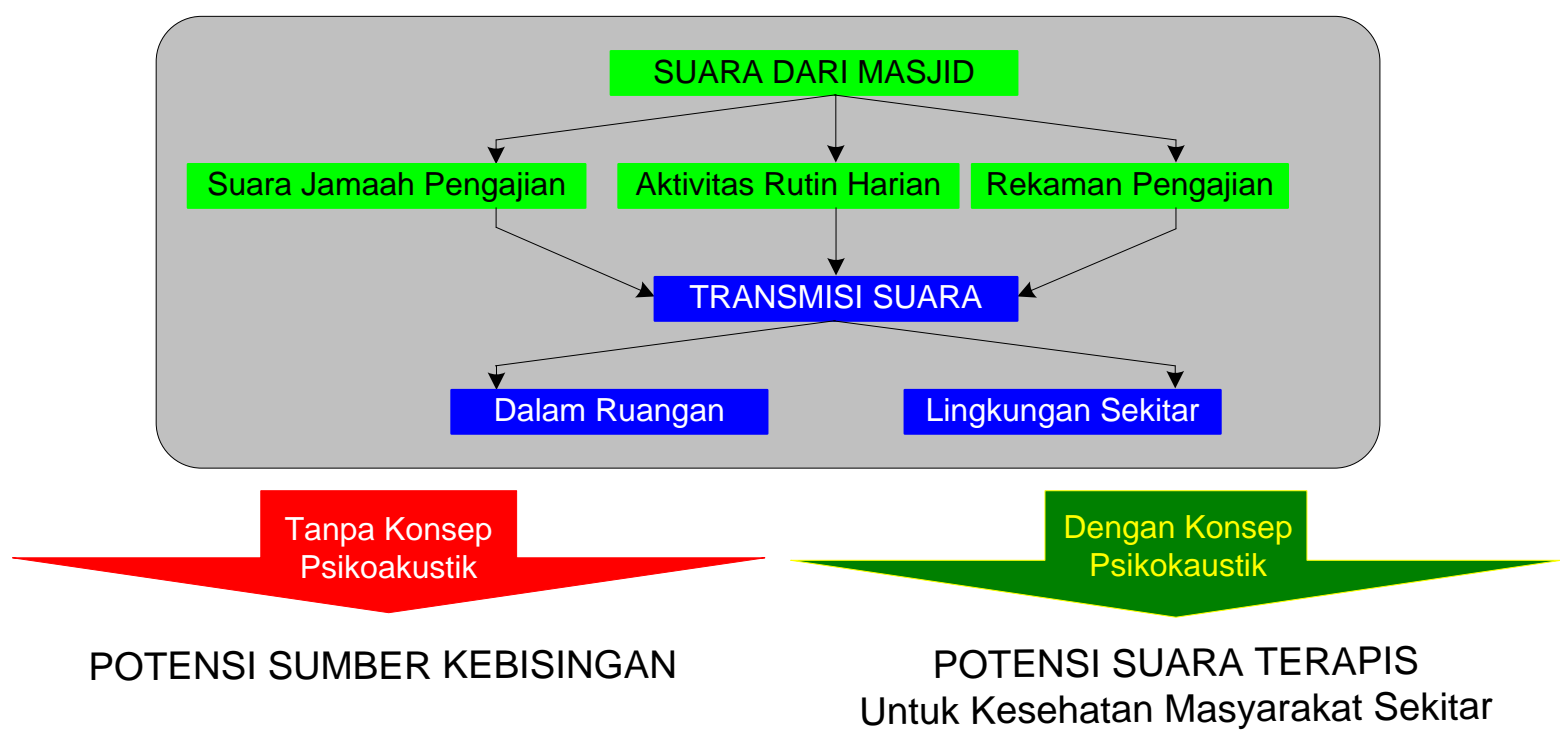

Gambar 2. Konsepsi aplikasi psikoakustik pada sistem pengeras suara masjid.

\section{Kesimpulan}

Suara-suara dari masjid yang berupa suara-suara jamaah pengajian, ceramah, maupun kegiatan ibadah harian rutin, jika dikelola secara baik berlandaskan pada pemahaman lingkup ilmu psikoakustik, bisa berpotensi menjadi suara-suara terapis. Suara-suara terapis berbasis pengajian sudah banyak ditemui dan diteliti meski dalam lingkup terbatas. Membangun sistem pengelolaan dan pengendalian suara masjid yang konsisten dapat mentransformasikan suara-suara yang awalnya dimaknai sebagai satu sumber kebisingan menjadi suara alami pembangun kesehatan masyarakat yang berjalan otomatis. Ketercapaian hipotesis ini dapat dilakukan dari penerapan suatu kegiatan penelitian dan/atau pengabdian pada masyarakat oleh institusi-institusi pendidikan atau dinas-dinas terkait.

\section{Daftar Referensi}

Adytya, B. (2020). 9 Unsur-Unsur Musik Beserta Penjelasan Lengkapnya. Trending Dalam Merdeka.Com. Https://Www.Merdeka.Com/Trending/9-Unsur-Unsur-Musik-Beserta-PenjelasanLengkapnya-KIn.Html?Page=All

Alawiyah, T. (1997). Strategi Dakwah Di Lingkungan Majelis Taklim. Penerbit Mizan.

Anonim. (2018). Pengajian. Wikipedia. 
GANDRUNG: Jurnal Pengabdian Kepada Masyarakat ISSN: 2721-6136 (Online)

Armand, M. (2015). TOA Masjid Dan Sedikit Tentang Kebisingan. Kompasiana.

Bauer, E. (2002). Music Of The Spheres. Spirit Of Ma'at, 3.

Camara, J., Ruszkowsky, J., \& Worak, S. (2008). The Effect Of Live Classical Piano Music On The Vital Signs Of Patients Undergoing Ophthalmic Surgery. Medscape J Med., 10(6), 149.

Everest, F. (1987). Fundamentals Of Sound, In Handbook For Sound Engineers: The New Audio Cyclopedia (3rd Ed.). Howards W. Sams \& Co.

Everest, F. A. (1987). Fundamentals Of Sound. In Handbook For Audio Sound Engineers: The New Audio Cyclopedia (Pp. 3-22). Http://Www.Amazon.Com/Handbook-Sound-Engineers-AudioCyclopedia/Dp/0240803310

Finahari, N., Rubiono, G., \& Soebiyakto, G. (2016). Comparing The Spectral Profiles Of The Javanesse Gending With The Classical Music As The Therapeutical Music. Biomed. Eng. UB, 2(1), 19-23.

lakovides, S. A., Iliadou, V. T. H., Bizeli, V. T. H., Kaprinis, S. G., Fountoulakis, K. N., \& Kaprinis, G. S. (2004). Psychophysiology And Psychoacoustics Of Music: Perception Of Complex Sound In Normal Subjects And Psychiatric Patients. Annals Of General Hospital Psychiatry, 3, 4-7. Https://Doi.Org/10.1186/1475-2832-3-6

Irianto, A. (2009). Upaya Meningkatkan Kemampuan Pitch Control Dengan Menggunakan Notasi Angka Pada Siswa Kelas VIII SMP 3 Kudus Tahun Pelajaran 2008/2009. Universitas Negeri Semarang. Krumhansl, C. (2000). Music And Affect: Empirical And Theoretical Contributions From Experimental Psychology (In Greer,). Oxford University Press.

Maratos, A., Gold, C., Wang, X., \& Crawford, M. (2009). Music Therapy For Depression. Cochrane Database Of Systematic Reviews 2008, 1, Art. No.: CD004517.

Mohamad, S. P., Yusoff, M. Y. Z. M., \& Adli, D. S. H. (2013). Terapi Bunyi Melalui Bacaan Al-Quran Bagi Masalah Emosi Dan Kemahiran Motor Pertuturan Kanak-Kanak Autistik. QURANICA, International Journal Of Quranic Research, 5(2), 53-72.

Padmodarmaya, P. (1987). Tata Dan Teknik Pentas Untuk SMK. Departemen Pendidikan Dan Kebudayaan.

Parstoday, R. (2018). Fungsi Dan Peran Masjid (47). Pars Today.

Platel, H., Baron, J., Desgranges, B., Bernard, F., \& Eustache, F. (2001). Semantic And Episodic Memory Of Music: A Positron Emission Tomography Study. Neuroimage, 13, S727.

Purnamaningtyas, F. (2019). Penerapan Teknik Relaksasi Dengan Terapi Murotal Terhadap Pengurangan Nyeri Pada Pasien Post Orif Fraktur. Universitas Muhammadiyah Magelang. 
GANDRUNG: Jurnal Pengabdian Kepada Masyarakat ISSN: 2721-6136 (Online)

Rilla, E. V., Ropi, H., \& Sriati, A. (2014). Terapi Murottal Efektif Menurunkan Tingkat Nyeri Dibanding Terapi Musik Pada Pasien Pasca Bedah. Jurnal Keperawatan Indonesia, 17(2), 74-80.

Rina P, L. A., Muchamad Dachlan, L., \& Wahyuni. (2017). Perbedaan Pengaruh Terapi Musik Klasik Terhadap Penurunan Tekanan Darahpada Penderita Hipertensi Pra-Lansia Usia 45-59 Tahun Dengan Lansia Usia 60-74tahun Di Dusun Guwosari Karangmalang Sragen. Stikes 'Aisyiyah Surakarta.

Safitri, A. (2012). Perbandingan Manfaat Terapi Distraksi Musik Klasik Mozart Dan Langgam Jawa Terhadap Tingkat Nyeri Dan Kecemasan Pada Ibu Primipara Di Puskesmas Mergangsan Dan Jetis Yogyakarta. Universitas Muhammadiyah Yogyakarta.

Wahid, A. (2019). Masjid Di Era Milenial: Arah Baru Literasi Keagamaan (J. Jahroni \& I. Abubakar (Eds.)). Pusat Kajian Agama Dan Budaya UIN Syarif Hidayatullah Jakarta.

Wati, L., Purwaningsih, W., \& Susilowati, T. (2018). Penerapan Terapi Musik Mozart Untuk Menurunkan Dismenorea Di Kampunggriyan Pajang Laweyan Surakarta. STIKES 'Aisyiyah Surakarta. 